\title{
Chairman/CEO Duality and its Effects for the Management of Corporate Governance in Guayana
}

\author{
Adebimpe Lincoln ${ }^{1,2}$, Richard Fields ${ }^{2}$ \& Oluwatofunmi Adedoyin ${ }^{1}$ \\ ${ }^{1}$ School of Management, Cardiff Metropolitan University, Cardiff, United Kingdom \\ ${ }^{2}$ School of Law, University of Liverpool, Liverpool, United Kingdom \\ Correspondence: Adebimpe Lincoln, School of Management, Cardiff Metropolitan University, Cardiff, UK., \\ CF5 2YB, Wales, United Kingdom. Tel: 29-20-416-392. E-mail: blincoln@cardiffmet.ac.uk
}

Received: July 8, 2013

doi:10.5539/ijbm.v8n20p36
Accepted: August 22, 2013

Online Published: September 22, 2013

URL: http://dx.doi.org/10.5539/ijbm.v8n20p36

\begin{abstract}
This research provides a detailed analysis of board leadership structure of corporations in Guyana focusing on whether individual boards are duality or separately led. There were two questions being asked at the outset. First, would duality led or separately led companies prove more likely to achieve profitability and financial success. Secondly, if neither, was there some other configuration of the board that would be successful in the time frame under study. The study is of significant importance because up to the present time there is no empirical research which expresses an opinion on the phenomenon based on evidence of local experience. It was intended to establish that the conclusions drawn regarding these arrangements in companies in the developed world were not apposite in the Guyanese context and to discover what conclusions were relevant locally. To this end the research sought to develop a Guyanese position based on various metrics which were extracted from the Annual Reports of the target companies spanning a three year period i.e. 2009-2011. The evidence is certainly suggestive if it is not compelling that there is a substantive relationship between board leadership structure and business success in the marketplace of Guyana. Further study is needed, perhaps with a wider window maybe of a ten year period as that would be likely to provide even more persuasive evidence of a correlation between leadership structure and performance.
\end{abstract}

Keywords: corporate governance, $\mathrm{CEO} /$ chairman, duality, Guyana

\section{Introduction}

As a result of recent corporate failures in various countries around the world the unique role played by directors has come under tremendous scrutiny and has led to legislation excerpts codifying director's duties and responsibilities. It is clear that director's ability to fulfil their responsibilities has an impact on shareholders, investors and the public, indeed on all stakeholders. Ponnu (2008) in his paper asks the question, what is corporate governance and he suggests that the answer is that which is concerned with ways of bringing the interests of investors and managers into harmony and ensuring that firms are run for the advantage of investors. In essence good corporate governance generates investor confidence and goodwill. The idea here is that people looking for a safe and profitable investment for their money will naturally prefer a well organised entity that is being run on demonstrably sound principles. This it is suggested is evident where sound corporate governance practices are being demonstrated. Gillan (2006) in his study asserts that many regard the board of directors as the "lynchpin" of corporate governance. He further states that the board has a fiduciary obligation to its shareholders and is responsible for the direction and monitoring of the business. Certainly, on this basis, not only the leadership of the board but the board itself is of pivotal importance to the health of the company. Consequently, this study examines the benefits and drawbacks of having the board led by one individual filling the roles of Chairman and Chief Executive Officer (CEO) known as duality.

According to Finkelstein and D'Aveni (1994) boards of directors have to ensure that CEOs carry out their duties in a manner that enhances shareholder interests. They assert that CEO duality creates contrasting effects that boards must try to balance. This is because on the one hand it can entrench a CEO at the apex of a corporation thus eroding a board's ability to monitor and discipline. Conversely, CEO duality is said to create a unified command structure which brings certainty and decisiveness to decision making consequently fostering stakeholder confidence. Duality is said to enhance the board's management posture as well as giving it access to 
more comprehensive and timely information (Vo, 2010). Also, it is said to unify the board's command structure and provide consistent leadership direction and engender the development of a collegial and collaborative environment. On the other hand where the leadership of the board is in the hands of separate Chairman and CEO, the perception is that having a Chair who is not a company executive brings fresh knowledge and insight into the board's decision making, providing unique experiences that enhance the board's management capabilities. Where the CEO is the Chairman, the board is not able to monitor and control the CEO despite its legal responsibility to do so. It is suggested in the study by Cannella and Lubatkin (1993) that duality gives the holder such institutional power that they have the capacity to forestall their own removal for any reason including non-performance, this is usually described as entrenchment. The counter argument to that assertion is that even in those cases the board still has the power to hire and fire the CEO, even though it is admitted that where there is duality this might be more difficult (Brickley, Coles \& Jarrell, 1997).

Harrison, Torres, \& Kukalis (1988) concluded in their exposition that organizations tend to consolidate leadership in response to external pressures in order to centralise power and control of the entity. Promoting the opposing point of view Finkelstein and D'Aveni (1994) posit that CEO duality represents a conflict of interest where the CEO with responsibility for the overall management of the company also has to evaluate the success of the strategy. They further suggest that vigilant boards tend to favour non-duality since the alternative leads to entrenchment of the CEO who is then difficult to replace if he proves to be deficient in any way. Furthermore, the $\mathrm{CEO}$ is said to be able to dominate both the content and the agenda of board meetings. In highlighting the importance of the role of boards of directors Weisbach (1987) states that the board is the shareholders' first line of defence against incompetent management, if need be it would replace an errant CEO. The position in Guyana is far from clear cut mainly because the problem has not been previously analysed so that impressions are largely the result of anecdotal evidence as opposed to empirical study. This research will attempt to demonstrate which of the two principal systems is better suited to the local setting. Consequently, the central aim of this research is to engage in a critical analysis of the leadership structure of corporations in Guyana with particular attention being paid to whether the boards of directors are duality or separately led. It will be argued that the conclusions drawn from studies in the developed world do not necessarily apply to the situation in Guyana which has peculiarities that distinguish it from the outside world generally and from the First World particularly.

\section{Literature Review}

\subsection{The Board of Directors and Its Leadership Structure}

In the United States (US) the practice of combining the positions of CEO and Chairman, known as duality is not uncommon (Brickley et al., 1997). A fairly exhaustive study undertaken by Kang and Zardkoohi (2005) came to the conclusion that non-dual structures compared with dual structures are shown to have no particular advantages for shareholders. If we accept this conclusion as valid then it appears that the preference for duality in the US derives from this being a well-established habit. The opposite is true of the situation among corporations in the United Kingdom (UK) where corporate governance codes establish a clear preference for the two posts to be separately held (Financial Reporting Council, 2006). The Cadbury Committee (1992) is very clear that good governance requires the positions of Chairman and CEO to be held by separate persons and this has been adopted by other codes in operation in the UK and Europe. Mellor (2006) in discussing the origins of the Combined Code stated that the Cadbury Committee realised that boards needed freedom to press their companies forward but that it should be done using a system that provided accountability. The Combined Code goes on to provide that there should be clear division of leadership of the company and that one person should not hold the positions of Chairman and CEO. It is clear that the business culture, or at least the regulatory culture, in the UK is decidedly in favour of a division of the leadership functions at the top of companies.

Despite it being common, in recent times, duality has come under considerable pressure in the US from diverse groups, among them being shareholder activists and regulators. According to Brickley et al., (1997) the argument is that separating the positions will reduce agency costs and improve corporate performance. Apart from examining the leadership structure of the board it should be noted that the board has basically a dual function of its own, that is to say it has a management function and a monitoring function (Vo, 2010). According to Vo (2010), the board's management function includes setting the direction and policies of the company, its financial strategies and compensation plans and making important decisions concerning the firm. On the other hand in its monitoring role the board oversees the hiring of management employees and generally ensures that management maintains proper standards of performance in the firm.

Corporate governance codes have recently focussed, inter alia, on director independence. Ritchie (2007) is of the opinion that the idea of independent directors is promoted because it is thought to improve company 
performance through superior corporate governance but he goes on to say that many studies have placed a question mark on that assumption. The question of director independence has become important in both the US as well as the UK in light of recent corporate collapses around the globe. In the US Section 301 of the Sarbanes-Oxley Act of 2002 which came into being in response to the corporate scandals of the time such as Enron, requires companies to have audit committees composed entirely of independent directors. In the UK Sections 171-173 of the Companies Act 2006 sets out the duties and standards required of directors with particularity, including a duty to act within his powers, to promote the success of the company, to exercise independent judgement and Section 175 states that directors must avoid conflicts of interest. Complementary to the Companies Act 2006 are the Cadbury code (1992) and the UK Corporate Governance Code (2012) which also highlights the need for director independence. So it is clear that the independence of directors is considered to be important on both sides of the Atlantic.

In Guyana the Corporate Governance Code (2011) proclaims in its preamble that it was developed as a joint effort of both the public and private sectors and further states that it does not "describe mandatory or enforceable principles" but that it sets out "good corporate governance practice". The Guyana Corporate Governance Code (2011) requires that at least half the number of directors on a board shall be independent directors. Ram (2011) notes that the Guyana Code suggests that there is a rebuttable presumption of non-independence in several circumstances including if the director has been an employee of the company or group within the last five years; participates in the company's share option or a performance-related pay scheme, or is a member of the company's pension scheme; has close family ties with any of the company's advisers, directors or senior employees; holds cross-directorships or has significant links with other directors through involvement in other companies or bodies; represents a significant shareholder; or has served on the board for more than nine years from the date of their first election. These are very modern ideas on director independence but are culled from the developed world and are not necessarily suggesting themselves out of a local or regional experience. Regulators and others should be encouraged to 'think local' in much the same way as they seek to encourage the populace to 'buy local'.

\subsection{The Pros and Cons of Duality and of Separate Leadership}

A prominent theoretical perspective as stated earlier suggests that duality effects a saving in costs in relation to information transfer between or among the leaders of the company and also if there is only one person at the helm then there is no need for any transfer to take place which obviously results in a saving. The avoidance of the need to transfer information obtained under duality is said to improve the ability of the executive to perform the function of the office entrusted upon him/her (Harris \& Helfat, 1998). One school of thought holds that, in accordance with agency theory which is based on the premise that the owners of a shareholding company are the principals and the managers are the agents, the owners would do better if they were in direct control of the company (Donaldson \& Davis, 1991). Vo (2010) suggests that the combined position has great potential for improving the board's management role, even though this might be at the expense of the board's ability to monitor the behaviour of executive conduct. Duality of command in the company is said to reduce the cost of decision making particularly in relation to the speed in taking and implementing decisions (Baliga, Moyer, \& Rao, 1996). The separate position enhances the board in terms of its management posture by promoting the timeliness and quality of the board's decision making. Also, they assert that the board function in its monitoring role is better when there is a non-executive Chairman. The reasoning is that the board is unable to monitor the CEO if he is also the Chairman. Vo (2010) opines that where the positions are combined the CEO/Chairman is able to handpick board members for the various committees of the board and by the use of that power to exert considerable influence over important groups such as the compensation committee. Conversely, where the posts are separately held the CEO is lacking that ability and, it is suggested, is therefore more under the control of the Chairman and the board.

Baliga, et al (1996) instance that separation creates the potential for rivalry between the two leaders of the company as well as confusion in the public mind as there are two seemingly authentic spokesmen in the company. Finkelstein and D'Aveni (1994) posit that vigilant boards tend to favour separation since they hold that duality promotes CEO entrenchment and can lead to behaviour that reduces shareholder wealth. Duality also leads to domination of the board agenda and of the content of board meetings by the CEO/Chairman because of the extraordinary control the combined post gives him/her which permits him/her to appoint loyalists to the board thus strengthening an already dominant position. Brickley et al., (1996) in their investigation assert corporate governance promoters and regulators feel that corporate governance is more efficient and of greater effect when the two principal positions are in separate hands. They claim that the separate chairman position makes the board's management function easier since it allows the board to make decisions quickly and adopt 
different strategies as required by changing business environments. It is also suggested that separating the two principal positions allows the board to perform its monitoring role better through the instrumentality of a non-executive Chairman. Correspondingly, it is claimed that duality restricts the board from the ability to monitor and qualify the behaviour of the executive managers (Finkelstein \& D'Aveni, 1994). It is suggested by some that having the two principal positions combined effects a saving in agency costs which is obtained where there is separation in the corporation between control and ownership (Vo, 2010). On the other hand those who support the contrary position say that in the case of a separate chairman the agency costs still exists, however they are directed to controlling the separate chairman's behaviour (Brickley et al., 1996). However, Vo (2010) is of the view that in this latter case the agency costs will be lower than when the board is controlling a combined CEO/Chair. Baliga et al. (1996) Finkelstein and D'Aveni (1994) agree that the combined position of $\mathrm{CEO} /$ Chairman puts directors in the difficult position of having to assess a CEO who is also their leader on the board and to whom they have to look for assignments and nominations.

While the focus of this research is on the leadership structure of corporations it cannot neglect the role played by the rest of the board members. We adverted earlier to agency theory which, as we defined, relates to the situation where the owners are the principals and the executive managers are their agents, in which situation the leadership of the corporation, whether single or dual, will depend for their success on the degree to which their subordinate board members are able to carry out their duties effectively. One commentator noted that agency costs are adversely affected by corporate decisions made by agents who are influenced by private interests (Bebchuk, Cremers \& Peyer, 2008). The argument here is that their decisions, in these circumstances, are not made optimally to further shareholder interests. Dalton and Kesner (1987) note in their paper that where the management of companies act more in their personal interest than on behalf of the shareholders the board of directors has failed to police and control such management. Entrenchment is a fear which encourages the argument that the two top positions should be separated on the premise that a board, in the case of being duality led, has no incentive to discipline its head and thus the probability of entrenchment is more real (Canella \& Lubatkin, 1993).

\subsection{Corporate Governance Mechanisms in Guyana}

Corporate governance refers to the set of systems, principles and processes by which a company is governed. Corporate Governance has developed fairly rapidly since the corporate scandals that have occurred in the US and Europe, starting with the Enron collapse and particularly as a reaction thereto (Mallin, 2012). Since then elaborate codes have been drawn up and introduced with varying degrees of compulsion in all the developed markets one of the important ones in the UK being the Cadbury Report. The Cadbury Report was so named after the Chairman of the Committee that drew it up, Sir Adrian Cadbury. This committee was set up following on the BCCI scandal and published its report in 1992. In Guyana the Council of the Private Sector Commission (PSC) on April 7, 2011 accepted a Code on Corporate Governance which could have some transformational effect on the way Guyana companies are managed (Ram, 2011). Even a casual comparison of the two codes reveals the striking resemblance the one bears to the other in parts. That fact is particularly interesting to this research since the Guyana code inveighs against CEO duality. The only problem is that this trenchant position is not born out of any experience or evidence coming out of the Guyanese ethos but has just been cribbed from the Cadbury code. It would really be better for those who observe independence days with much bacchanalia to learn to fashion their own ways and means based on their own well observed and understood circumstances. The readiness with which prescriptions seemingly from on high are followed without question can be depressing to the thoughtful mind. The practice of promulgating a principle without sound evidence on which to base the expectation that it benefits those who must act on it is questionable. This hardly inspires confidence in those who must operate the Code, and leads to doubts about other aspects of the Code which have similarly been lifted and similarly dumped without ceremony into the Guyanese milieu.

Fortunately, observance of the code by Guyanese companies is on the comply or explain basis which has also been taken from the UK so that even though firms should not practise duality they still do with great success and with an explanation to their stakeholders. This principle of comply or explain came into being with the Cadbury Code which gave companies the option to follow the best practices set out in the code or to explain to their shareholders why to do so was not appropriate in the company's peculiar circumstances. Hogg (2010) offers three rationale for the technique as a desirable corporate governance mechanism, which are, in summary, that it leaves decisions on appropriateness in the hands of managers and shareholders who it chiefly concerns, it recognises the possibility of achieving good governance by other means and by allowing flexibility it enables the code to set more demanding standards. La Porta, Lopez-de-Silanes, Shleifer \& Vishny (2000) in their work define corporate governance as a set of mechanisms by which outside investors protect their investment against 
expropriation by insiders. In this context insiders are a reference to the managers and controlling shareholders of the entity. In short corporate governance can be seen as playing an important part in rendering a company attractive to investors. The Code provides that every company ought to be led by an effective board and it makes a specific recommendation in its second Principle that the Chairman and the CEO shall be separate persons. Ram (2011) examines aspects of the Guyana corporate governance code, particularly the first section which addresses the position of Directors. He points out that the code mandates that the Chairman and the CEO must be different persons. He reiterates and he goes on to report that "the 'big man' culture in Guyana is for a unification of these functions into one holder." Reference made here to the Guyanese colloquialism to describe the all-powerful supreme figure that occupies the duality role in some of the companies under study. Ram (2011) clearly does not approve of this phenomenon and does not mind showing his biases. He observes that "Guyana has larger-than-life incumbents in these positions in various corporations".

\section{Methodology}

Guyanese business demonstrates many aspects of the free enterprise system, and the legal arrangement of the corporate business world is along the lines of developed capitalist pattern. In particular the legal arrangements for companies are laid down in the Companies Act 1991. Under Section 154 of the Act, all companies are required to submit annually, a document called the Annual Return to the Registrar of Companies. The Annual Return requires a company to submit a report, signed by a director or the secretary, on a number of features of the company including a certified true copy of a balance sheet, profit and loss accounts and group accounts. The return has also to comply with the requirements of the Fifth Schedule to the Companies Act 1991 which sets out a number of disclosures concerning the company's shares and the company's indebtedness. The Schedule also requires the provision of information on the names and addresses of all persons who are shareholders of the company and all those who have ceased to be shareholders since the last return. A perusal of this return will enable us glean a wealth of information about essential aspects of a company's business and its performance annually, as well as its state of financial health.

The target sample includes all Guyanese public companies and Insurance companies. The rationale for choosing public companies is that they are subject to the same government regulation. Likewise the rationale for choosing insurance companies is that although they are not shareholding entities, their with-profit policyholders who have voting rights at general meetings are very much like shareholders and they are similarly all under government regulation. Therefore, bearing in mind the differences comparisons can still validly be made. Data was collected from the annual report of the sample companies for the financial year ending 2009, 2010 and 2011. In order to be able to assess the relative strengths of the companies in the sample and to gauge their performance over time simple descriptive statistics on a range of spectrum of financial variables was adopted to investigate the characteristics and performance of the duality firms compared to the non-duality firms. Return on assets (ROA) i.e. net income/average assets, Return on Equity (ROE) i.e. net income/average common stockholders equity, Earning per Share (EPS) i.e. net income/wighted average of common share outstanding and Gross Profit Margin (GPM) i.e. net income/turnover was used to measure firm performance.

It is to be noted that the operations of insurance companies do not lend themselves to the use of certain ratios such as EPS (since there are no shareholders) and GPM (since there is no trading in goods). The one exception is the Demerara Fire and General Insurance Company Limited which is a wholly owned subsidiary of the Demerara Life Assurance Society Limited which owns all its shares. It will have the EPS metric but it also does not trade and therefore will not have a GPM shown. By way of substitution for the missing ratios of the insurance companies being studied, the ratio of Return on Revenue (ROR) is introduced. ROR is a measure of the profitability of a company which compares its net income to its revenue. It is also called the net profit margin. This is a useful tool for comparing a company's performance from year to year, since it compares the net income and the revenue the only difference between which is the expense of the company. Both of these amounts are derived from the company's income statement and net income is also described as profit after tax.

\section{Results and Discussion}

Table 1-8 contain the financial ratios obtained from the company annual reports. Since the study seeks to examine the effects, if any, of board leadership structure on the performance of these companies, it is essential to identify three companies which are duality led for comparative study; they are Banks DIH Ltd, Demerara Distilleries Ltd (DDL) and Guyana Stockfeeds (Stockfeeds). All the other companies have the principal offices in different hands. Stockfeeds might well be viewed as a special case in that the Chairman/CEO is also the principal shareholder. 
Table 1. Ratio analysis for public companies (return on equity)

\begin{tabular}{clcc}
\hline Company Name & \multicolumn{2}{c}{ Return on Equity (PAIT/ Avg Shareholder's equity*100) } \\
\hline Citizens Bank & 2011 & 2010 & 2009 \\
Demerara Bank Limited & 22.60 & 17.98 & 15.12 \\
Republic Bank Ltd & 22.57 & 21.49 & 26.23 \\
Guyana Bank for Trade and Industry & 21.07 & 24.57 & 26.43 \\
Banks DIH Limited & 19.79 & 19.82 & 19.25 \\
Demerara Distillers Ltd. & 11.55 & 8.13 & 7.77 \\
Caribbean Containers Inc. * & 11.75 & 7.49 & $(3.92)$ \\
Demerara Tobacco & $(0.50)$ & $(0.57)$ & 178.59 \\
Sterling Products Ltd. & 242.47 & 205.22 & 6.45 \\
Guyana StockFeeds Inc. ${ }^{*}$ & 6.82 & 5.97 & 11.59 \\
\hline
\end{tabular}

*Caribbean Containers Inc: Dep. is taken out before calculation of gross profit.

* Guyana StockFeeds Inc.: Sales after discount allowed was used in GP Margin.

Table 2. Ratio analysis for public companies (return on asset)

\begin{tabular}{llll}
\hline Company Name & & Return on Asset (PAIT/Avg Assets*100) \\
\hline Citizens Bank & 2011 & 2010 & 2009 \\
Demerara Bank Limited & 2.59 & 2.22 & 1.88 \\
Republic Bank Ltd & 2.79 & 2.65 & 2.97 \\
Guyana Bank for Trade and Industry & 1.93 & 2.14 & 2.10 \\
Banks DIH Limited & 2.01 & 2.07 & 1.92 \\
Demerara Distillers Ltd. & 9.15 & 6.44 & 6.00 \\
Caribbean Containers Inc. * & 6.21 & 3.77 & 4.43 \\
Demerara Tobacco & $(0.43)$ & $(0.47)$ & $(3.15)$ \\
Sterling Products Ltd. & 106.51 & 96.04 & 84.86 \\
Guyana StockFeeds Inc. ${ }^{*}$ & 5.68 & 5.03 & 5.43 \\
\hline
\end{tabular}

*Caribbean Containers Inc: Dep. is taken out before calculation of gross profit.

* Guyana StockFeeds Inc.: Sales after discount allowed was used in GP Margin. 
Table 3. Ratio analysis for public companies (earnings per share)

\begin{tabular}{llcc}
\hline Company Name & \multicolumn{2}{c}{ Earnings Per Share (Net Profit/ \# of shares) } \\
\hline Citizens Bank & 2011 & 2010 & 2009 \\
Demerara Bank Limited & 13.53 & 8.99 & 6.57 \\
Republic Bank Ltd & 2.19 & 1.90 & 1.82 \\
Guyana Bank for Trade and Industry & 6.43 & 6.61 & 6.07 \\
Banks DIH Limited & 34.57 & 30.11 & 24.79 \\
Demerara Distillers Ltd. & 1.93 & 1.36 & 1.12 \\
Caribbean Containers Inc. ${ }^{*}$ & 1.55 & 0.92 & $(0.54)$ \\
Demerara Tobacco & $(0.07)$ & $(0.08)$ & 39.86 \\
Sterling Products Ltd. & 57.80 & 48.45 & 6.32 \\
Guyana StockFeeds Inc. ${ }^{*}$ & 7.42 & 6.18 & 1.57 \\
\hline
\end{tabular}

*Caribbean Containers Inc: Dep. is taken out before calculation of gross profit.

* Guyana StockFeeds Inc.: Sales after discount allowed was used in GP Margin.

Table 4. Ratio analysis for public companies (gross profit margin)

\begin{tabular}{llll}
\hline Company Name & \multicolumn{2}{l}{ Gross Profit Margin (Profit from operations/turnover*100) } \\
\hline Banks DIH Limited & 2011 & 2010 & 2009 \\
Demerara Distillers Ltd. & 14.29 & 12.98 & 12.30 \\
Caribbean Containers Inc. ${ }^{*}$ & 28.33 & 26.40 & 33.08 \\
Demerara Tobacco & 17.14 & 16.31 & 11.13 \\
Sterling Products Ltd. & 56.54 & 55.63 & 54.86 \\
Guyana StockFeeds Inc. ${ }^{*}$ & 22.64 & 25.26 & 24.37 \\
\hline
\end{tabular}

*Caribbean Containers Inc: Dep. is taken out before calculation of gross profit.

* Guyana StockFeeds Inc.: Sales after discount allowed was used in GP Margin.

Table 5. Ratio analysis for public companies (net interest margin)

\begin{tabular}{llll}
\hline Company Name & \multicolumn{4}{l}{ Net Interest Margin (Net Interest income/Interest income*100) } \\
\hline & 2011 & 2010 & 2009 \\
\hline Citizens Bank & 74.04 & 68.33 & 64.41 \\
Demerara Bank Limited & 65.94 & 48.07 & 47.54 \\
Republic Bank Ltd & 84.29 & 83.39 & 81.32 \\
Guyana Bank for Trade and Industry & 74.32 & 70.33 & 66.46 \\
\hline
\end{tabular}

The ROA metric shows that Demerara Distilleries Ltd and Guyana Stockfeeds all have a healthy position which is superior to the other companies except for Demerara Tobacco Co Ltd. The clear implication of these numbers is that the leadership and the management of these companies are functioning well. Block (2003) in his investigation of the effects of leadership in business concluded that leadership is at the heart of effective management in today's marketplace regardless of one's place within the organizational hierarchy. He goes on to say that the attitudes of those in authority affect the actions of employees. Demerara Tobacco Co Ltd is a subsidiary of British American Tobacco plc of the United Kingdom which used to but no longer does any manufacturing in Guyana and is a very small operation which is run by about six persons (Ram, 2009). Ram 
(2009) states that the company enjoys a monopolistic position without any of the controls that monopolies are normally subjected to, such as government regulation to control prices or to set a rate of return. This is important because of the dominant position of the monopoly and so as to protect the consumer. Also it operates in a captive market with a habit forming product, namely, tobacco as its only commodity. These peculiarities disqualify the company as a useful object of our study particularly as its results would tend to distort our investigation.

Looking at the ROE metric we observe almost the same situation with the duality companies doing better but admittedly not as good as the banking companies. Indeed the banking companies as a group all have a very robust looking financial profile which probably can lead to the justifiable conclusion that in this industry the leadership structure of these companies is of no great significance to their success. This argument is tenable because the banking companies are seen to be performing better than the other separately led companies and therefore it is reasonable to conclude that their success is more to do with the nature of their activity rather than their leadership structure. In relation to EPS the results are decidedly mixed and do not bear the position as in the previous two metrics. Can any worthwhile conclusions be drawn from this or is it the way it is because of the share structure of each entity? It may be that further study is needed in understanding the significance of this result but it does not assist either of the two kinds of leadership structure that we are considering. In relation to the GPM percentage, we find once again that the duality led companies are showing a very sound financial position, but on this occasion they are joined by Sterling Products Ltd (Sterling). Sterling had not shown any impressive results regarding the ROE and ROA figures whereas in comparison Banks DIH Ltd, Demerara Distilleries Ltd had demonstrated a strengthening position every year of the three year window we are examining. The fact that these companies operate in virtually the same market place and business environment would seem to suggest that the duality led companies are operating more impressively and it would be reasonable to attribute this to the kind of leadership structure these companies have. Many corporate governance scholars would question this since they have concluded that duality in leadership of companies makes no difference to business success but these come from studies conducted in the developed world. A more relevant study is that conducted by Lam and Lee (2008) in Hong Kong which concluded that CEO duality prevails over non-duality in non-family firms. This is precisely the situation in Guyana. The companies in the target group are all non-family firms. It should be mentioned that both Banks DIH Ltd, Demerara Distilleries Ltd are in the liquor and beverage business though both companies have diversified beyond just that activity (Ram, 2012). Whether this is significant for the results we are looking at in relation to the leadership structure of the business is difficult if not impossible to glean from a mere examination of the metrics we have developed.

Table 6. Ratio analysis for insurance companies (return on equity)

\begin{tabular}{llll}
\hline Company Name & \multicolumn{2}{l}{ Return on Equity (PAIT/ Avg Shareholder's equity*100) } \\
\hline & 2011 & 2010 & 2009 \\
\hline Demerara Mutual & 1.23 & 4.33 & 3.47 \\
The Guyana and Trinidad Mutual Fire & 4.82 & 7.09 & 6.48 \\
Demerara Fire and General & 5.12 & 12.03 & 1.77 \\
Hand-in-Hand - Mutual Life & 5.02 & 2.72 & 0.26 \\
\hline
\end{tabular}

Table 7. Ratio analysis for insurance companies (return on asset)

\begin{tabular}{llll}
\hline Company Name & \multicolumn{2}{l}{ Return on Asset (PAIT/Avg Assets*100) } \\
\hline & 2011 & 2010 & 2009 \\
\hline Demerara Mutual & 1.14 & 2.67 & 3.17 \\
The Guyana and Trinidad Mutual Fire & 4.01 & 5.78 & 5.29 \\
Demerara Fire and General & 2.31 & 4.58 & 0.42 \\
Hand-in-Hand - Mutual Life & 4.80 & 2.59 & 0.25 \\
\hline
\end{tabular}


Table 8. Ratio analysis for insurance companies (earning per share)

\begin{tabular}{llll}
\hline Company Name & \multicolumn{2}{l}{ Earning Per Share (Net Profit/ \# of shares) } \\
\hline Demerara Mutual & 2011 & 2010 & 2009 \\
The Guyana and Trinidad Mutual Fire & N/A N/A \\
Demerara Fire and General & N/A & N/A & N/A \\
Hand-in-Hand - Mutual Life & 27.01 & 27.01 & 27.01 \\
\hline
\end{tabular}

All of the insurance companies in tables 6,7 and 8 have boards in which the principal offices are in different hands and their performance does not compare with that of the duality led companies. It is true that insurance as a business is quite different from the commercial companies that make up the target group so that too fine a point should not be made about their performance in comparison with the duality led companies. Suffice it to say that in the circumstances no inference can be drawn from their performance that is adverse to the idea that duality led companies will likely prove superior in the Guyana marketplace.

The argument for separation at the top has many facets, perhaps the classical commentary on this problem is the one by Brickley et al. (1997) which states inter alia that in the US achieving combined titles, that is duality, is the "equilibrium" and that having separate titles usually indicates that succession is taking place or that some other transitory event is occurring. They go on to argue that separating the titles ignores the important issue of the incentives for the non CEO Chairman. They say that while it is true that having an outside director Chairman might reduce the agency costs of limiting the CEO's behaviour it introduces the new agency costs of dealing with the behaviour of the non CEO Chairman. In short substituting one set of costs for another. The authors point to the enormous power an outside Chairman would have over such things as the hiring and firing of the CEO and the setting of the agenda, and the fact that this position of power would enable him to "extract rents" from the company. They posit that since the CEO is possessed of considerable specialised knowledge about the company then the separation creates problems such as causing the incomplete transfer of critical information between the now separated CEO and Chairman, which they deem to be costly to the company. It is apposite to note that all of these observations and comments made by Brickley et al., (1997) are made in the context of the US experience. The US is a very highly developed country with a long commercial history and it seems inappropriate, to say the least, that Guyana a small recently independent third world country should adopt these experiences and arguments without careful examination and trial, yet that is the import of adopting the Guyana corporate governance code as it is promulgated.

One example can illustrate the strength of this observation. In Guyana there is never going to be any confusion about who speaks on behalf of any company be it duality or separately led. This is because of the smallness and intimacy of the society the authentic voice of any company is what lawyers call a notorious fact and therein lays an essential difference between the local and the international scenario. Be that as it may for historical and other reasons former colonial countries will for a long time continue to ape the former colonial power even where there is no obvious justification for so doing, but also in cases where they feel, justifiably, that so doing creates a good impression and encourages business opportunities. In those circumstances the idea that separation at the top of companies is a desirable corporate governance goal is an obvious lift from the developed western world and even though, to date, we have no evidence from the local experience that this is a good and desirable thing to strive for nonetheless we have it almost as holy writ.

Vo (2010), in her comprehensive discourse on the topic opines that those who favour duality say that if it were not an effective and successful form of governance public companies could not practise that form of leadership and still survive in the competitive atmosphere of the marketplace. Vo (2010) draws attention to the belief among commentators that duality provides the company with a unified command structure and a collegial atmosphere for board discussion and in which to make decisions. In support of the contrary position Vo (2010) states that a CEO/Chair may not have the critical approach required to vet information that has been screened by the CEO, which is the normal route of information to the board, before such is passed on to the board. Also, the concentration of power and authority in one person, the CEO/Chair, would tend to restrict board oversight and limit unnecessarily the room to strategise and adapt to changing commercial environments.

However, more research is needed to be able to prognosticate with absolute certainty that this conclusion will stand the test of time. It was probably more than coincidence that the two most successful companies both 
duality led were in the same line of business and were therefore direct competitors, i.e. Banks DIH Ltd and Demerara Distilleries Ltd. It was observed that among the public companies insurance companies had to be treated differently because, not being trading entities they were not susceptible to producing the GPM metric nor in most cases the EPS metric. Also their overall results did not make them competitive with the others in terms of commercial success although they were all individually financially healthy. It will be useful and instructive to examine other aspects of corporate governance apart from the leadership structures of companies to see whether there is a discernible effect from those aspects on the business performance of firms in Guyana since other studies in other parts of the world have shown that the mix of internal as opposed to independent directors could be crucial to the success of a company. Abdullah (2004), in his study among Malaysian listed companies which made use of similar financial metrics came to the conclusion that neither board independence nor leadership structure had any effect on firm performance and that board independence was negatively associated with the firm's leadership structure, that is to say, that when a firm is duality led the percentage of outside directors to the board size is lower. Such an investigation could profitably be undertaken in Guyana because this study has demonstrated that the local marketplace is sufficiently different to offer new insights that would inform local practice to the advantage of the business population.

\section{Conclusion}

This research has sought to provide a detailed analysis of board leadership structure of corporations in Guyana focussing on whether individual boards are duality or separately led. The object of the exercise has been to determine the relative performance of those companies by examining the results gleaned from their Annual Reports and to detect, if possible, the influence, if any, of the board leadership structure in bringing about such performance. In his very instructive study Abdullah (2004) tells us that a board of directors is responsible for setting corporate goals which are directed to realising long term shareholder value. Further, he says that the board is responsible for assessing the rectitude of the strategies and approaches used by management in executing the corporate goals. It is clear that the board's role is pivotal to the success of the company. For this reason in this research we have studied the effect the leadership structure of boards in Guyana has on business success. In particular we have looked critically at the phenomenon of CEO duality as compared to the position where the principal offices are in separate hands. Dalton, Daily, Ellstrand, \& Johnson (1998) carried out a detailed study of the same kind of search for an indication that leadership structure in companies had a substantive relationship to business success and they came to a very discouraging conclusion where they stated that the results for the board composition/financial performance meta-analyses suggest no relationship of a meaningful level/Subgroup moderating analysis based on firm size, the nature of the performance indicators, and operationalization of board composition provide no evidence of moderating influences for these variables as well. The evidence derived from the meta-analysis and moderating analysis for board leadership structure and financial performance has the same character and shows no evidence of a substantive relationship. Maybe such a daunting conclusion must give the researcher pause but only that. The evidence is certainly suggestive if it is not compelling that there is a substantive relationship between board leadership structure and business success in the marketplace of Guyana. Further study is indicated, perhaps with a wider window maybe of a ten year period as that would be likely to provide even more persuasive evidence of a correlation between leadership structure and performance.

\section{References}

Abdullah, S. N. (2004). Board composition, CEO duality and performance among Malaysian listed companies. Journal of Corporate Governance, 4(4), 47-61. http://dx.doi.org/ 10.1108/14720700410558871

Baliga, B. R., Moyer, R. C., \& Rao, R. S. (1996). CEO duality and firm performance: What's the fuss? Strategic Management Journal, 17, 41-53. http://dx.doi.org/ 10.1002/(SICI)1097-0266(199601)

Bebchuk, L. A., Cremers, M., \& Peyer, U. (2008). CEO Centrality. John M. Olin Center for Law, Economics and Business. Working Paper no. 601. Retrieved from http://www.insead.edu/facultyresearch/faculty/personal/upeyer/research/documents/Olin601.pdf

Block, L. (2003). The leadership-culture connection: an exploratory investigation. Leadership and Organization Development Journal, 24(6), 318-334. http://dx.doi.org/ j.msl.2011.05.008

Brickley, J. A., Coles, J. L., \& Jarrell, G. (1997). Leadership structure: Separating the CEO and Chairman of the Board. Journal of Corporate Finance, 3(3), 189-220. http://dx.doi.org/10.1016/S0929-1199(96)00013-2

Cadbury Report. (1992). Report of the Committee on the Financial Aspects of Corporate Governance. Retrieved from http://www.ecgi.org/codes/documents/cadbury.pdf 
Canella, A. A., \& Lubatkin, M. (1993). Succession as a Sociopolitical Process: Internal Impediments to Outsider Selection. The Academy of Management Journal, 36(4), 763-793. http://dx.doi.org/ 10.2307/256758

Combined Code Principles of Good Governance and Code of Best Practice. (2000). Committee on Corporate Governance. Retrieved from http://www.ecgi.org/codes/documents/combined_code.pdf

Dalton, D. R., \& Kesner, I. F. (1987). Composition and CEO Duality in Boards of Directors: An International Perspective. Journal of International Business Studies, 18(3), 33-42. http://dx.doi.org/10.1057/palgrave.jibs.8490410

Dalton, D. R., Daily, C. M., Ellstrand, A. E., \& Johnson, J. L. (1998). Meta-Analytic Reviews of Board Composition, Leadership Structure, and Financial Performance. Strategic Management Review, 19(3), 269-290. http://dx.doi.org/ 10.1002/(SICI)1097-0266(199803)

Donaldson, L., \& Davis, J. H. (1991). Stewardship Theory or Agency Theory; CEO Governance and Shareholder Returns. Australian Journal of Management, 16(1), 49-64. http://dx.doi.org/10.1177/031289629101600103

Eisenhardt, K. M. (1989). Agency Theory: An Assessment and Review. Academy of Management Review, 14(1), 57-74. http://dx.doi.org/ 10.5465/AMR.1989.4279003

Financial Reporting Council. (2006). The UK approach to Corporate Governance. Retrieved from http://www.frc.org.uk/documents/pagemanager/frc/FRC\%20The\%20Uk\%20Approach\%20to\%20Corporate $\% 20$ Governance $\% 20$ final.pdf

Finkelstein, S., \& D'Aveni, R. A. (1994). CEO Duality as a Double-Edged Sword: How Boards of Directors Balance Entrenchment Avoidance and Unity of Command. Academy of Management Journal, 37, 1079-1108. http://dx.doi.org/ 10.2307/256667

Gillan, S. L. (2006). Recent Developments in Corporate Governance: An Overview. Journal of Corporate Finance, 12, 381-402. http://dx.doi.org/ 10.1016/j.jcorpfin.2005.11.002

Harris, D., \& Helfat, C. E. (1998). CEO Duality, Succession, Capabilities and Agency Theory: Commentary and Research Agenda. Strategic Management Journal, 19(9), 901-904. http://dx.doi.org/10.1002/(SICI)1097-0266(199809)

Harrison, J. R., Torres, D. L., \& Kukalis, S. (1988). The changing of the guard: Turnover and structural change in the top management positions. Administrative Science Quarterly, 33, 211-232. http://dx.doi.org/0001-8392/88/3302-0211

Hogg, C. (2010). The "Comply or Explain" Approach to Improving Standards of Corporate Governance. Retrieved from http://www.qfinance.com/corporate-governance-viewpoints/the-comply-or-explain-approach-to-improvingstandards-of-corporate-governance?page $=1$

Kang, E., \& Zardkoohi, A. (2005). Board Leadership Structure and Firm Performance. Corporate Governance: An International Review, 13(6), 785-799. http://dx.doi.org/ 10.1111/j.1467-8683.2005.00470.x

La Porta, R., Lopez-de-Silanes, F., Shleifer, A., \& Vishny, R. (2000). Investor protection and Corporate Valuation. National Bureau of Economic Research. Working Paper no. 7403. Cambridge, MA. Retrieved from

http://rru.worldbank.org/Documents/PapersLinks/investor_protection_origins_consequences_reform_latest. pdf

Lam, T. Y., \& Lee, S. K. (2008). CEO duality and firm performance: Evidence from Hong Kong. International Journal of Business in Society, 8(3), 299-316.

Mallin, C. A. (2012). Corporate Governance (3rd ed.). Oxford: Oxford University Press.

Mellor, J. (2006). The UK Combined Code on Corporate Governance and its application to Smaller quoted Companies. Bristol Business School. Retrieved from http://www.foundationgre.com/IFA\%20paper.pdf

Ponnu, C. H. (2008). Corporate Governance Structures and the Performance of Malaysian Public Listed Companies. International Review of Business Research Papers, 4(2), 217-230. Retrieved from http://www.bizresearchpapers.com/Paper-15.pdf

Ram, L. C. (2009). Demerara Tobacco Co Ltd Annual Report 2008. Retrieved from http://www.chrisram.net/?p=180 
Ram, L. C. (2011). Annual Reports 2011: Guyana Bank of Trade and Industry and Sterling Products Limited. Retrieved from http://www.chrisram.net/?cat=4

Ram, L. C. (2012). On the Line-Demerara Distillers Limited Annual Report 2011. Retrieved from http://www.chrisram.net/?tag=demerara-distillers-limited

Ritchie, T. (2007). Independent Directors: Magic Bullet or Band-Aid? Bond University, Corporate Governance eJournal. Retrieved from http://epublications.bond.edu.au/cgej/5

Vo, T. (2010). To Be or Not to Be Both CEO and Board Chair. Brooklyn Law Review, 76, 65-129.

Weisbach, M. S. (1987). Outside Directors and CEO Turnover. Journal of Financial Economics, 20, 431-460. http://dx.doi.org/ 10.1016/0304-405X(88)90053-0

\section{Copyrights}

Copyright for this article is retained by the author(s), with first publication rights granted to the journal.

This is an open-access article distributed under the terms and conditions of the Creative Commons Attribution license (http://creativecommons.org/licenses/by/3.0/). 